\title{
Kiesler'in Model Yapımındaki Haptik Deneyiminden Öğrenme: Harekattepe Tümülüsü'nün Diseksiyonları
}

\author{
Esen Gökçe ÖZDAMAR ${ }^{1 *}$
}

ÖZ

Bu makale Kiesler'in Sonsuz Evi'ndeki biçimsizlik algısından yola çıkar. Biçim, maddesellik, tektonik ve dokunsallık Sonsuz Ev'de korrealizm (correalism) düşüncesinin içerik ve bağlamı haline gelir.

Kiesler'in Sonsuz Evi'nde mekan, madde ve model ilişkine dair deneyimleme üzerinden yola çıkarak, biçimde belirlenimsizliğe değinmeye yönelik merak, Namık Kemal Üniversitesi mimarlık öğrencileri tarafından bir tümülüsün gövdesi disseksiyona (dissection) uğratılarak anlaşılmaya çalışıır. Burada amaç, Kiesler'in model yapımındaki kinestetik ve dokunsal algısına yönelik farkındalığı arttırmaktır.

Anahtar Kelimeler: Kiesler, Sonsuz Ev, model yapımı, dokunsal mimarlık

\section{Learning From Kiesler's Haptic Experience With Model Making: Dissections Of Harekattepe Tumulus}

\begin{abstract}
This article derives from the perception of the formless in Kiesler's Endless House. Form, materiality, tectonics and hapticity become the content and context of ideas of correalism within the Endless House.

Deriving from Kiesler's experimentation with space, material and the model in the Endless House, curiosity towards addressing the indeterminate in form was experimented with by dissecting the body of a tumulus as an architectural and crafts work by students of architecture at Namık Kemal University. This was done in order to raise kinaesthetic and haptic perception towards model making.
\end{abstract}

Keywords: Kiesler, Endless House, model making, haptic architecture

\footnotetext{
${ }^{1}$ Namık Kemal Üniversitesi, Güzel Sanatlar, Tasarım ve Mimarlık Fakültesi, Mimarlık Bölümü

* Illgili yazar/Corresponding author: egozdamar@nku.edu.tr, gokceozdamar@gmail.com

Gönderim Tarihi: 06.09.2017

Kabul Tarihi: 13.12.2017
} 
Kiesler'in Model Yapımındaki Haptik Deneyiminden Öğrenme: Harekattepe Tümülüsü’nün Diseksiyonları Learning From Kiesler's Haptic Experience With Model Making: Dissections Of Harekattepe Tumulus

\section{LEARNING FROM KIESLER'S HAPTIC EXPERIENCE WITH MODEL MAKING: DISSECTIONS OF HAREKATTEPE TUMULUS}

Friedrick Kiesler is one of the most influential avant-garde architects in the late modern period. He is known to create intersections between plasticity, form and the content of the building within a holistic life approach. He also contributed to architecture within a diverse set of disciplines, from stage design, exhibition space, theatre and art, to philosophy and science.

He saw the architecture profession as being a 'research practitioner,' and as such, this became an innovative model for architects for many years (Phillips, 2017, s. 2). Friedrick Kiesler's Endless House (1950s) and Greg Lynn's embryological houses (late 1990s) have a common ground in the sense that they both represent an overthrow ontology towards Cartesian thinking and modernist forms. Based on evolutionary biology and biomorphological patterns, these two states of thinking have a coherence in terms of their form, material and programs. The first estimates a haptic experience between architecture, body and correalism through experimental models, while the second approach evokes an evolution of pattern and digital computation interface. Kiesler and Lynn's experimental biomorphologic formations are not only an outcome of form, but have become a quest for content, context and a sensory environment.

The search for tectonics in architecture has been important, from Kiesler to Lynn, and has been evaluated as "the science or art of construction, both in relation to use and artistic design.' Tectonics, the art of making, refers not just to the 'activity of making the materially requisite construction that answers certain needs, but rather to the activity that raises this construction to an art form"' (Maulden, 1986, s.11).

Between emerging practices of parametric topologies and spaces and augmented realities, Kiesler's holistic approach towards creating a balance between life forces and the formation of space seems distant. His search for tectonics is visible both in his projects and in the process of model making. His mostly known unrealized project, The Endless House, is one of the case studies, or exemplars, that engage materiality, space and idea simultaneously, thus becoming a tectonic approach in architecture. The Endless House design evokes our lost senses and perception of a new world, while the spatial configuration evokes a mixing of poly-sense of haptic architecture. In doing so, it deals with all the senses at the same time and can enable a more holistic perception of the built environment.

Kiesler designed the Endless House as a single-family home for MOMA'S "Sculpture Garden" in 1958, and deemed it an 'eclectic, flexible habitat.' He saw the house as a composition of spaces and 'as elastic as the vital functions' (Moma (a), 2015). His project stated, 'function follows vision. Vision follows reality' (Moma (b), 2017). The Endless House opened the possibilities for the "impossible building," up the "Endless," to be built-somewhere, somehow-floating on water or elevated into the air" (Kiesler, 1966: 299). His new architecture was formulated as City in Space (1925), setting free from the ground, free space." He used new materials and (processing) techniques plastic, glass and pre-stressed concrete and by designing the Endless House, gave concrete a plastic character (Medicus, 2010: 32). Kiesler designed models with 
reinforced concrete on a wire mesh, with windows covered with a semi-transparent molded plastic (Sveiven, 2011). Moreover, Kiesler mentioned formlessness within the body of his model. The house consists of several intermeshing shells...This spatial arrangement also illustrates the architectural principle recurrently invoked by Kiesler: Loos's Raumplan, or space plan' (Zillner, 2010: 21).

In Kiesler, the form of the house became a tactile surface. Biomorphic form became formlessness in his design, as Kiesler combined life sciences with physicality. 'He says that forms are "the visible trading posts of integrating and disintegrating forces, mutating at low rates of speed." Furthermore, he defined co-realism as "the science of the exchange of relationships and forces, which emphasizes the dynamics of continual interaction between humanity and the environment, in which there is little or no distinction made between the natural and the technological"' (Mertins, 2007). For Kiesler, the house was a sensual body, with its organic and non-rectilinear space of intimacy (Phillips, 2005: 150) (Figures 1, 2, 3).

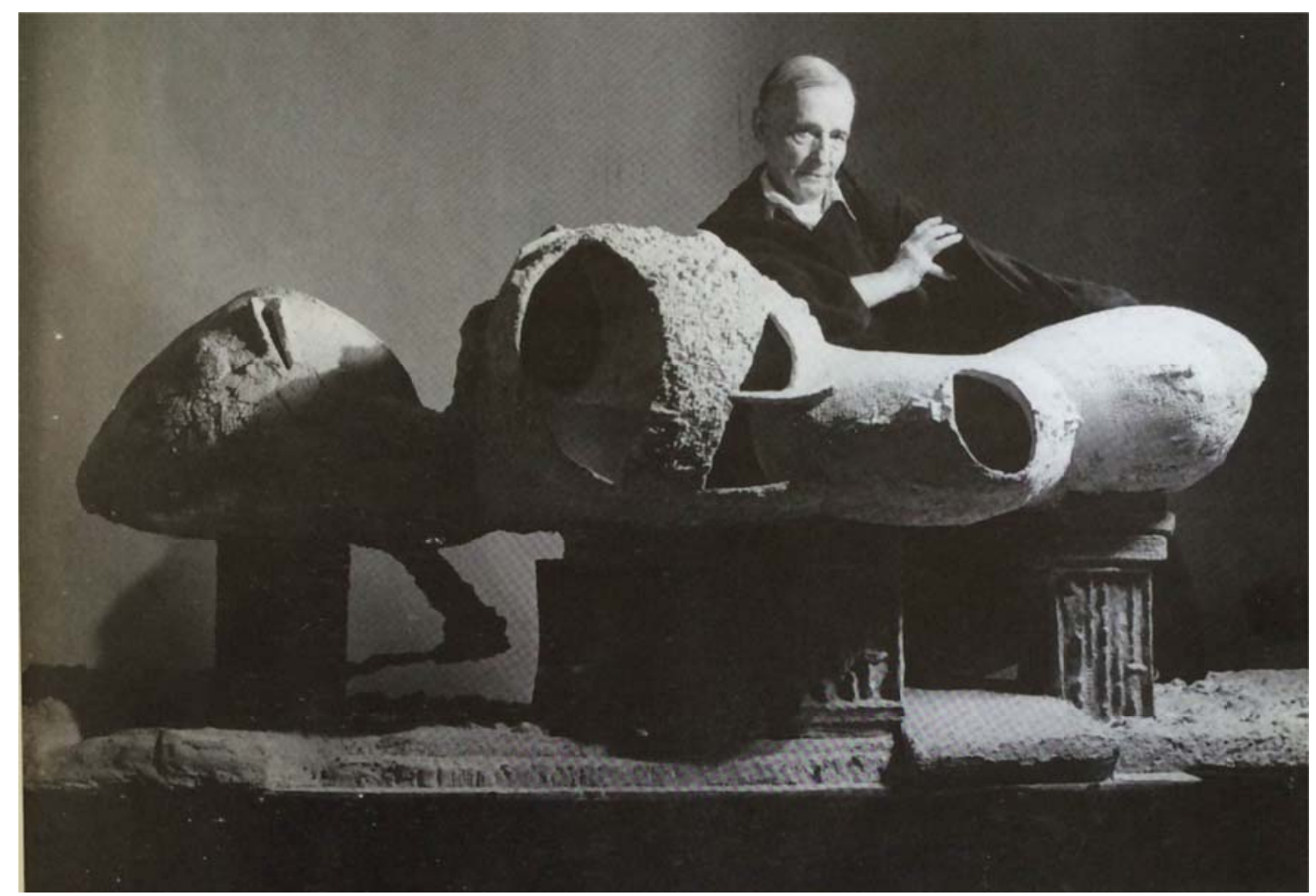

Fig. 1: Kiesler with the model for Endless House, around 1960 (Kiesler, 2003: 61). 
Kiesler'in Model Yapımındaki Haptik Deneyiminden Öğrenme: Harekattepe Tümülüsü’nün Diseksilyonları Learning From Kiesler's Haptic Experience With Model Making: Dissections Of Harekattepe Tumulus

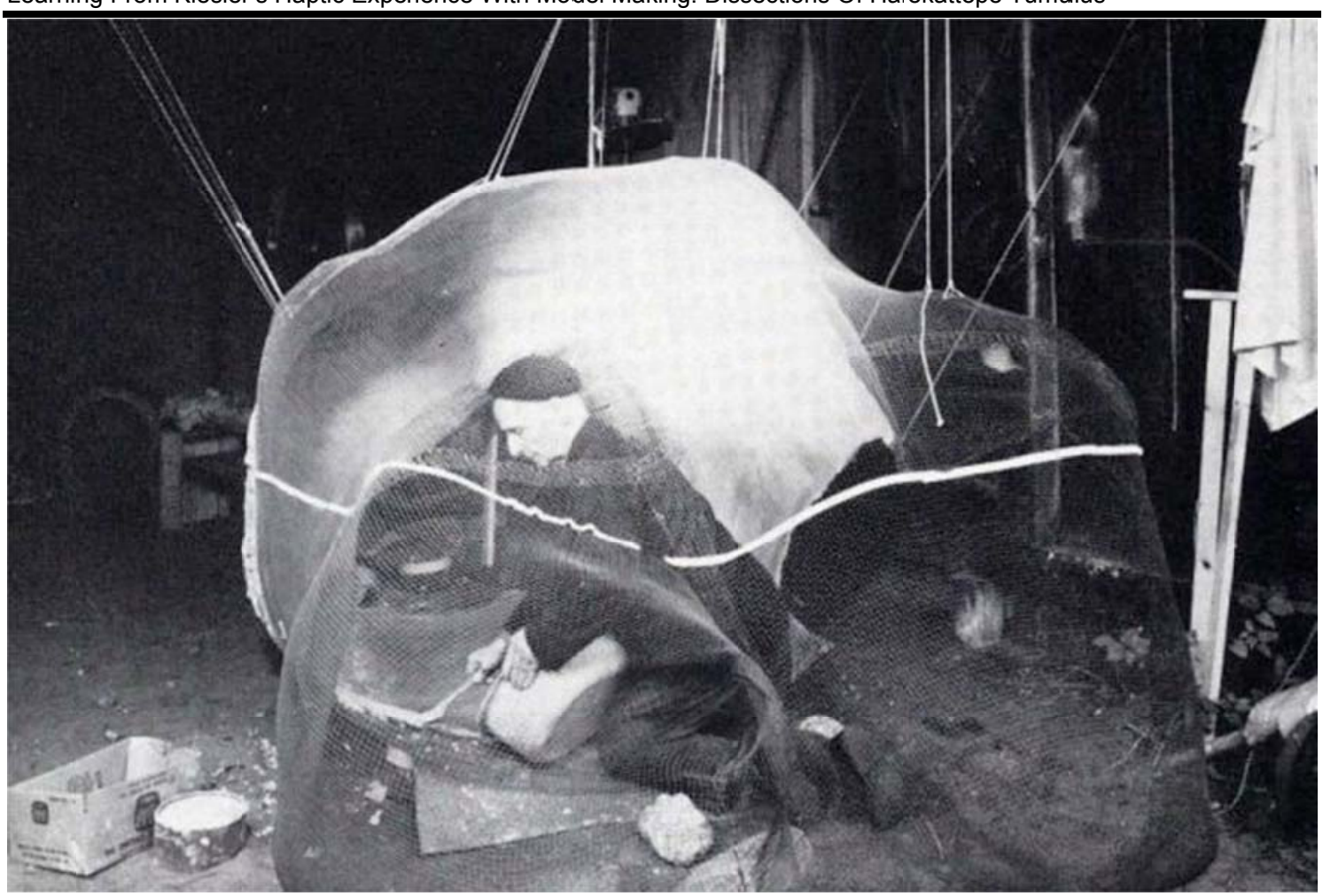

Fig. 2: Kiesler working on the Endless House (Sveiven, 2011).

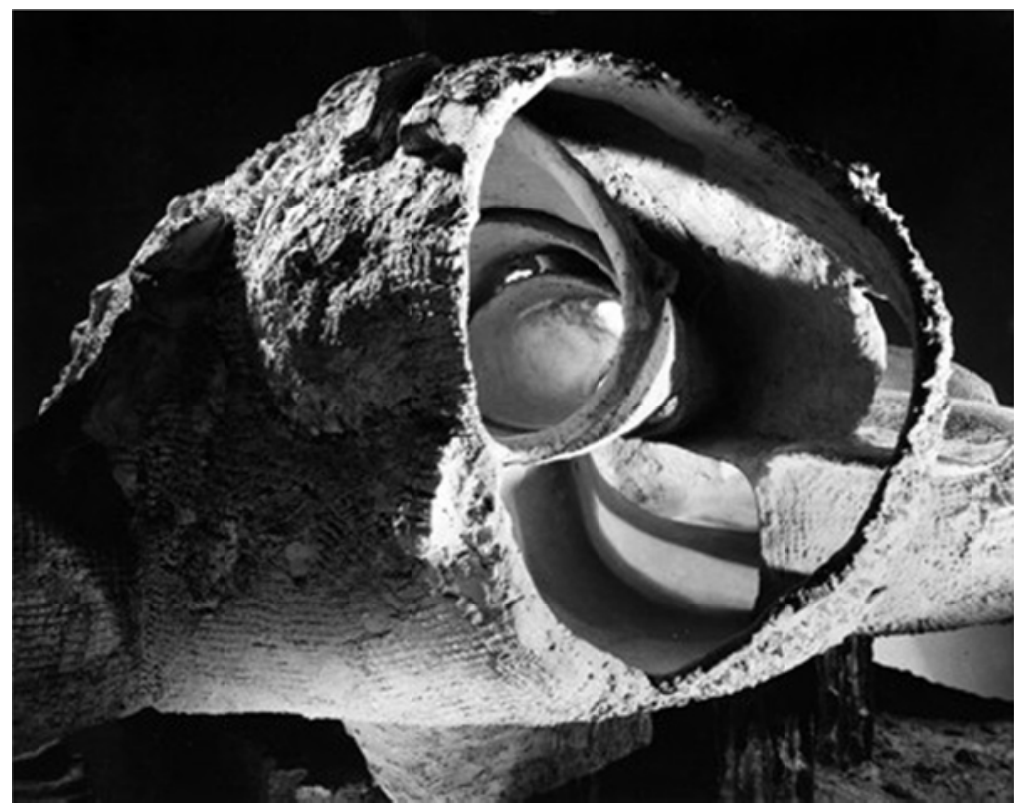

Fig. 3. Kiesler working on the Endless House (Sveiven, 2011).

He said, 'The Endless House is called "Endless" because all ends meet, and meet continuously. It is endless like the human body- there is no beginning and no end to it. The "Endless" is rather sensuous, more like the female body, in contrast to sharpangled male architecture' (Kiesler, 1966: 566). Space is continuous in the Endless House. 'All living areas can be unified into a single continuum' (Kiesler, 1966: 567). "For Kiesler, form ceases to be the key term because forms are always contingent. They're fluid, changing, they're a moment in between: you go from formlessness to 
form and then back to formlessness, and it keeps going. Form as a concept becomes nested inside this dynamic model of the universe and that changes it. Lissitzky put it beautifully back in 1924 when he stated, "Every form is the frozen instantaneous picture of a process. Thus, a work is a stopping-place on the road of becoming and not the fixed goal" (Mertins, 2007).

Kiesler's biomorphological form derived from a formless approach against modernity and its defined and accepted rational forms. As Kiesler mentioned, 'The era of experimentations in materials and forms over half a century has run its gamut; a new era has begun, that is an era of correlating the plastic arts within their own realms but with the objective of integrating them with a life freed from self-imposed limitations. The poet, the artist, the architect and the scientist are the four cornerstones of this newrising edifice' (Stiles, 2012: 602).

What is important in the Endless House is that the process and the product merge into each other by handcrafting. One is not followed by the other, but is fused together through making. Kiesler's design methodology cannot be read as a merely free form finding approach. He theorized the house on the idea of correalism; 'a broad philosophical outlook that considered the intrinsic interconnections between phenomena in the natural world and in human culture and life-it was anthropological (and ostensibly scientific) as much as it was architectural' (McGuire, 2015: 61-62). 'The house was intended to move in response to the body with seamless organic expression...Touch and vision are essential to the dynamic function of the house' (Phillips, 2005: 144) (Figure 4).
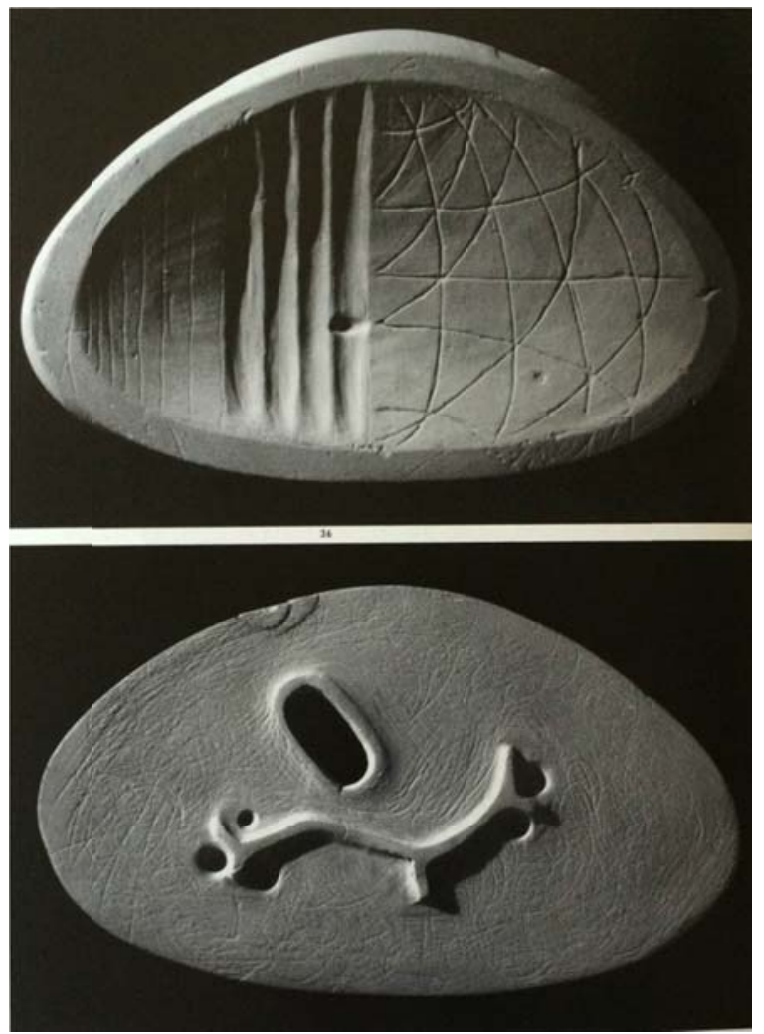

Fig. 4: Endless House model for the Kootz Gallery, 1950 (Kiesler, 2003: 44). 
Kiesler'in Model Yapımındaki Haptik Deneyiminden Öğrenme: Harekattepe Tümülüsü’nün Diseksiyonları Learning From Kiesler's Haptic Experience With Model Making: Dissections Of Harekattepe Tumulus

Similarly, Paul Virilio and Claude Parent addressed the theory of oblique function perception of an "oblique plane" as a construction of a tactile relationship between building and the body. In terms of touch and vision, the oblique was realized as idealized as the field by altering the relationship of space and weight, "which relates to the human body as a receptive totality." The oblique created a habitable surface and circulation, as well as the construction of an architecture that moved or evoked movement in mind. Like a simulation of topography or a landscape, the oblique created an "experienceable" surface, a body physically experienced in a space (Vyzoviti, 2004: 134).

Hands-on experience with the model is a sensory encounter with the space. By pouring model materials, Kiesler focused on indeterminate forms of physicality, which resulted as a formless and imageless approach. The approach becomes an intrinsic quality of form, structure and the narrative of the space. Hapticity is important in understanding the tectonics of form, as haptic engagement within the object is crucial in comprehending the object. Kiesler communicated through making and therefore, dematerializing architecture, making it a formless entity.

Kiesler reasserted the body's importance into an architecture climate (Krissel, 2003). 'The appreciation of immaterial architecture is complex and a challenge to the familiar, habitual experience of architecture. The richness of the user's experience of any building depends on an awareness of all the senses, but immaterial architecture may trigger a sense more often associated with the immaterial, such as smell, while questioning one more frequently associated with the material, such as touch' (Hill, 2005: 19).

\section{EXPERIMENTS ON DISSECTIONS OF HAREKATTEPE TUMULUS: BETWEEN NATURAL AND HUMAN-MADE ENVIRONMENT}

Haptic properties of the Endless House model create a "sensory experience" (Zillner, 2010: 21). Based on Kiesler's experimentation with space, material and the model, in the Endless House, curiosity towards addressing the indeterminate was experimented on by dissecting the body of a tumulus as an architectural and crafts element by students of architecture at Namık Kemal University. Here, instead of pouring model materials as Kiesler did, the act of dissecting became an understanding of endless topographies of space. Dissecting involved an approach to understanding space from the point of detail.

Dissection in art and architecture has been related to anatomy studies since the 14th century. Leonardo da Vinci and Michelangelo drew anatomical studies that provided "signs of these symbiotic relationships between artist and anatomist," where "fragmentation" of space and volume and "restructuring" gained importance (Costello, 2015: 25, 31). Corporeal knowledge was gained by dissecting bodies during the Renaissance in the 14th-17th centuries. 'Doctors and artisans sought to uncover the secrets it concealed. 'Renaissance doctors studied corpses to understand the nature of disease and Renaissance artists saw anatomical study as a way to broaden their mycological knowledge and to enhance the veracity of their human figures...they saw the process of dissection as a symbolic and intriguing narrative and understood the 
corpse's sensual interior as an analog for engaging artistic and architectural characteristics' (Costello, 2015: 14). The act of dissecting and fragmenting is observing, becoming familiar with what is already observed, and exploring the flesh of the form of matter.

Model making can enable kinesthetic and synesthetic perceptions. In model making, all senses, touching, tasting, hearing, vision and smell fuse instead of remaining separate. Recalling Kiesler's experimental model making, the students experienced the body of a tumulus as a potential space that could be evaluated as an infill and inhabitable space, imitating the dissecting of bodies during the Renaissance period. Inspired by anatomical dissections and Matta Clark's anarchitectural interventions through splitting buildings, which raised curiosity towards the invisible, the students focused on the dissection of an existing tumulus named Harekattepe, which is located in Tekirdağ. This dated to the 4th century BC during the Hellenistic period, through ceramic and largely made with plaster models. Regardless of the material, the motivation behind the modeling was to raise curiosity and learning built space by making and comprehending the void/solid relationship through the use of crafts.

Located on the highway between Tekirdağ and İstanbul, Harekattepe tumulus is an artificial burial mound, consisting of a stone and wood tomb placed inside of a soil hill. Excavated in 1997, Harekattepe tumulus is originally $22 \mathrm{~m}$ high with a diameter of $50-70$ meters and is one of the biggest and best-preserved tumuli in Thracia (Yıldırım, 2011: 122) (Figures 5, 6).

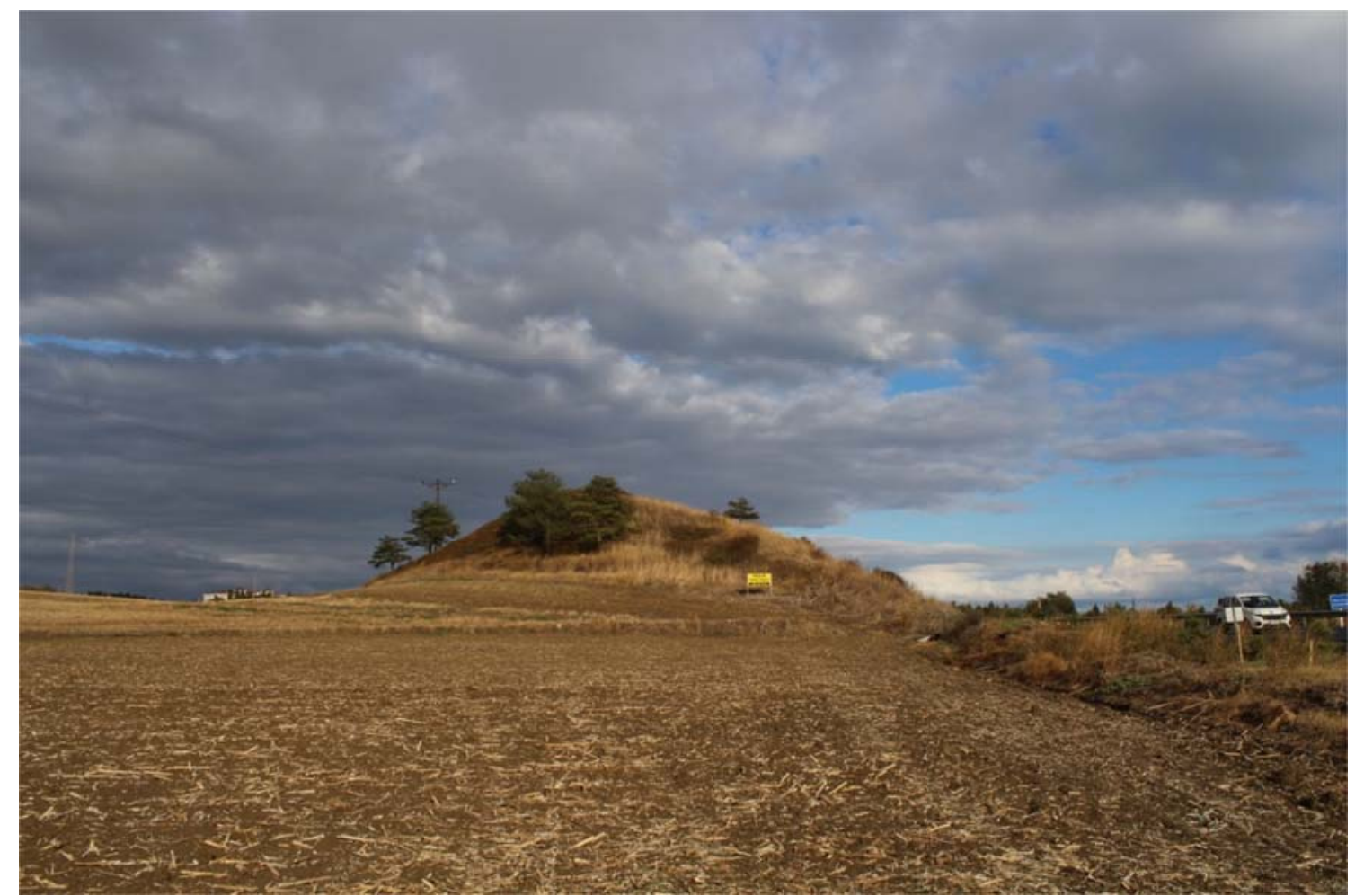

Fig. 5: Tumulus in 2016. Photo by the author, 2016. 


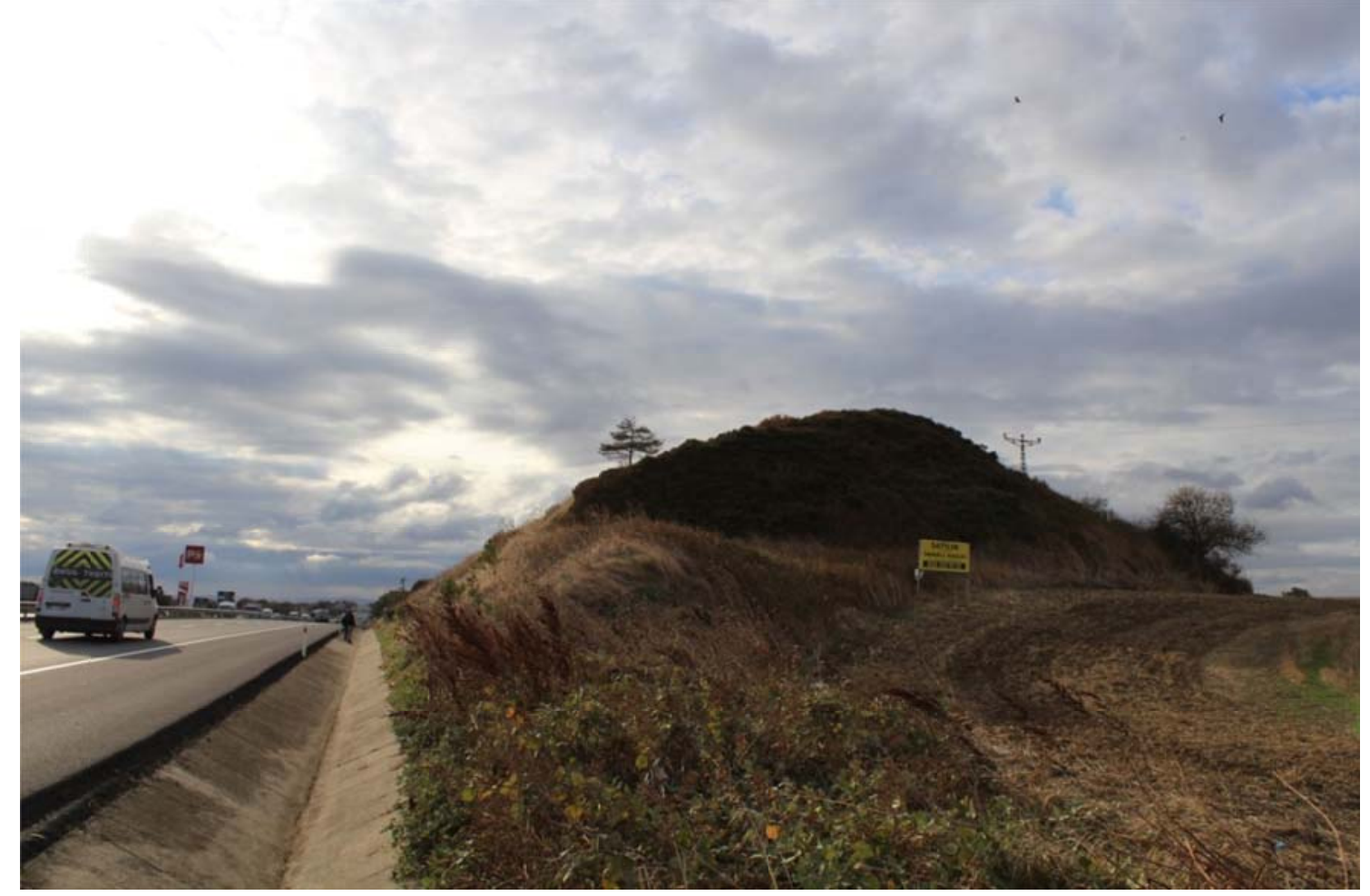

Fig. 6: Tumulus in 2016. Photo by the author, 2016.

Currently coated with natural vegetation and standing by the highway, the Harekattepe tumulus was examined through designs by the students of Architectural Studio I and III at Namık Kemal University within four weeks of the process. Students individually modeled Harekattepe Tumulus with plaster, gauze band and glue in 1/100 scale and then made an intervention to the void. The practices of dissection enabled spatial and haptic information, which was gathered from the interaction between the model and self.

As an initial exercise, first year students made abstractions and models of the void through any kind of material they found. Some of the students found it hard to model a void, but others modeled it with their bodies and corporeal movements, as well as with sprays filling the atmosphere.

After this exercise, first and second year students were informed about the history of the tumulus and the stratifications in excavation sites by the Archeological Department. Later, they confronted the excavations of the tumulus in the archeological museum. Through experimenting the void inside the tumulus and imagining a new narrative, they tried to make mappings and storyboards. The past was approached in terms of layers, with potential narratives between reality and fiction. Furthermore, pop-up models in images were constructed as part of the storytelling. Tumulus was evaluated as "bodies as external expression of a constructed interiority" (Wilde \& Ferber, 2012) through corporeal interventions. This experience enabled the students to extend their experience and to evaluate other existing buildings, as well as the natural environment, which becomes the key crucial issue in an architectural studio. Students designed dwelling spaces, a women's shelter, a library, a skateboarder space, a khan, a 
mushroom cultivation space and an archeological research centre, etc. Through this experimental approach, the practice of anatomical-corporeal dissection of the tumulus enabled the comprehending of a relationship between form and content of interiority, therefore opening up the flesh of the invisible space. This helped with understanding the boundaries of the void (Figures 7-18).

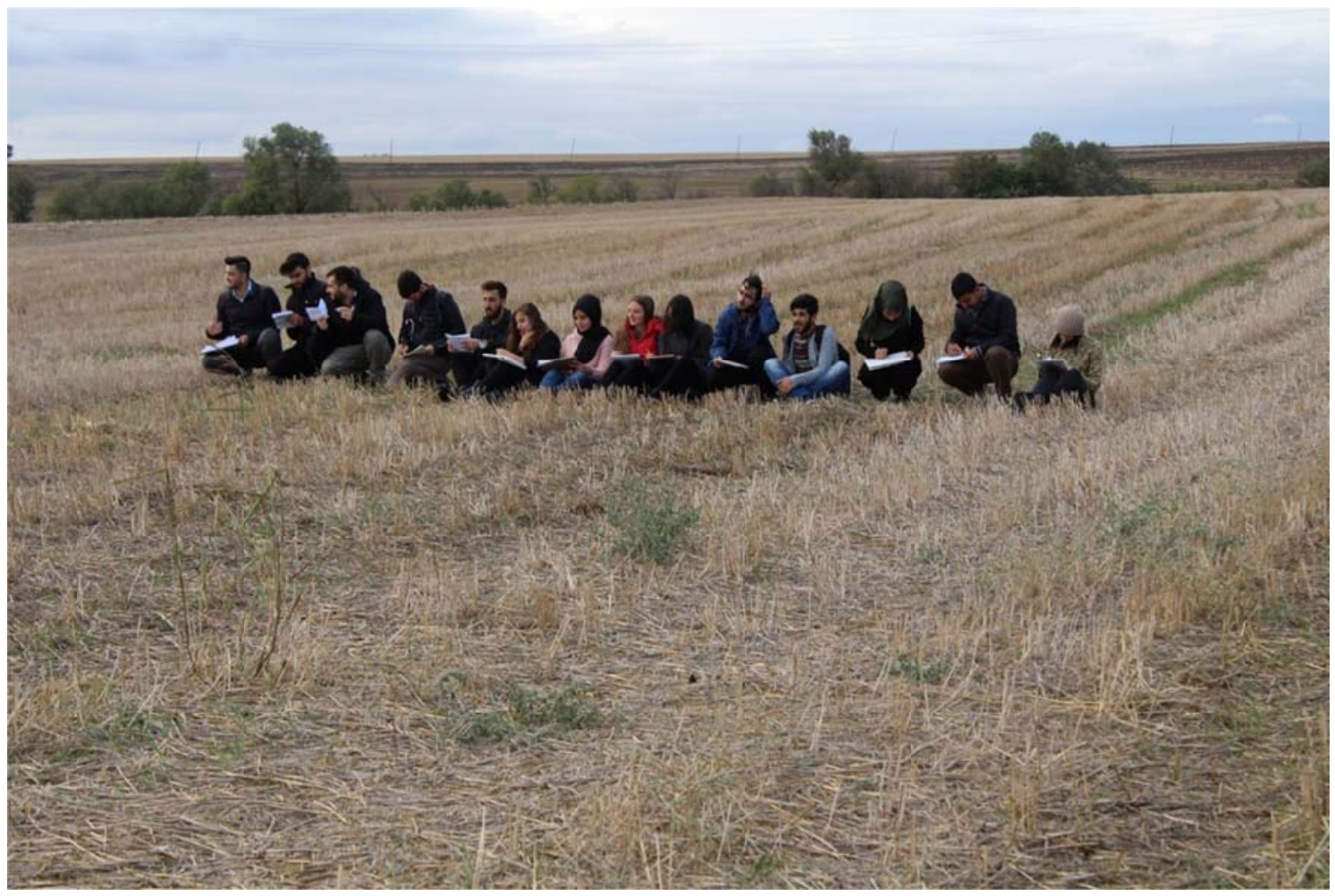

Fig. 7: Sketching of the tumulus. Photo by the author, 2016.

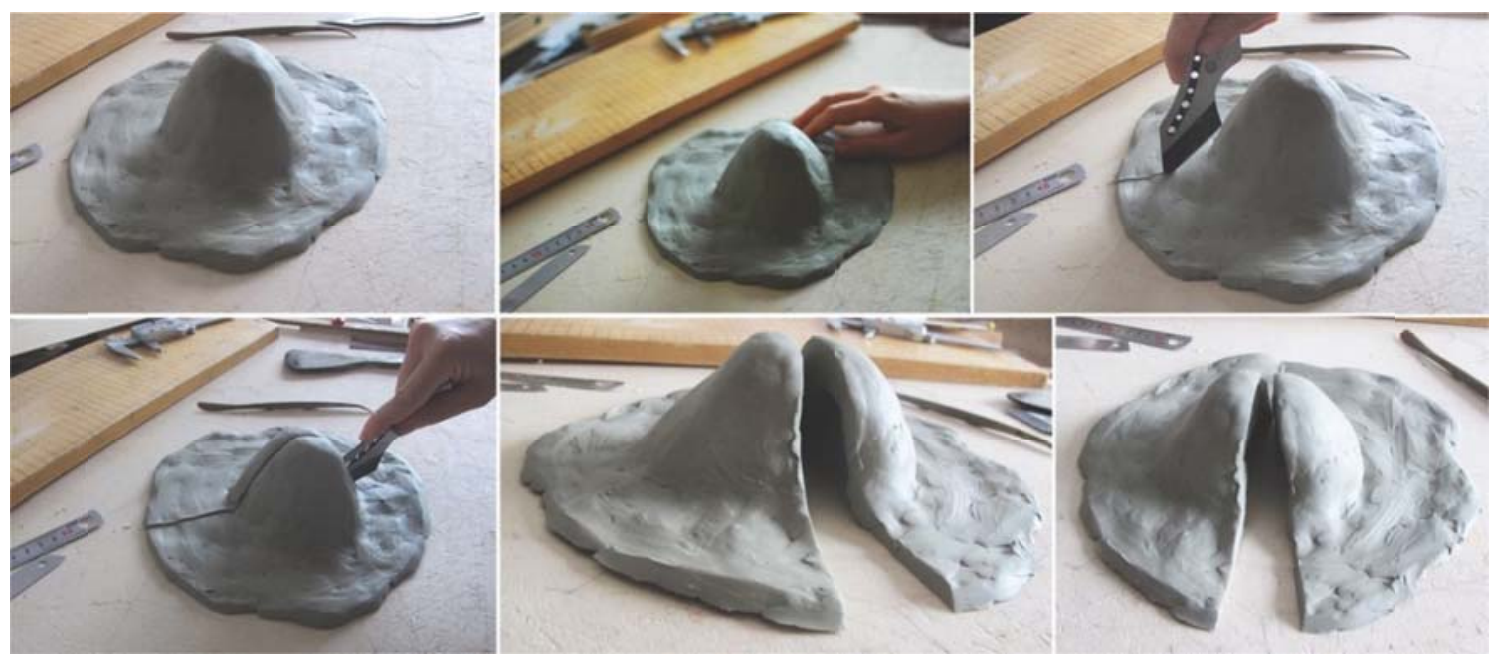

Fig. 8: Clay model of tumulus, 1/500 scale. Photo by the author, 2016. 
Kiesler'in Model Yapımındaki Haptik Deneyiminden Öğrenme: Harekattepe Tümülüsü'nün Diseksilyonları Learning From Kiesler's Haptic Experience With Model Making: Dissections Of Harekattepe Tumulus

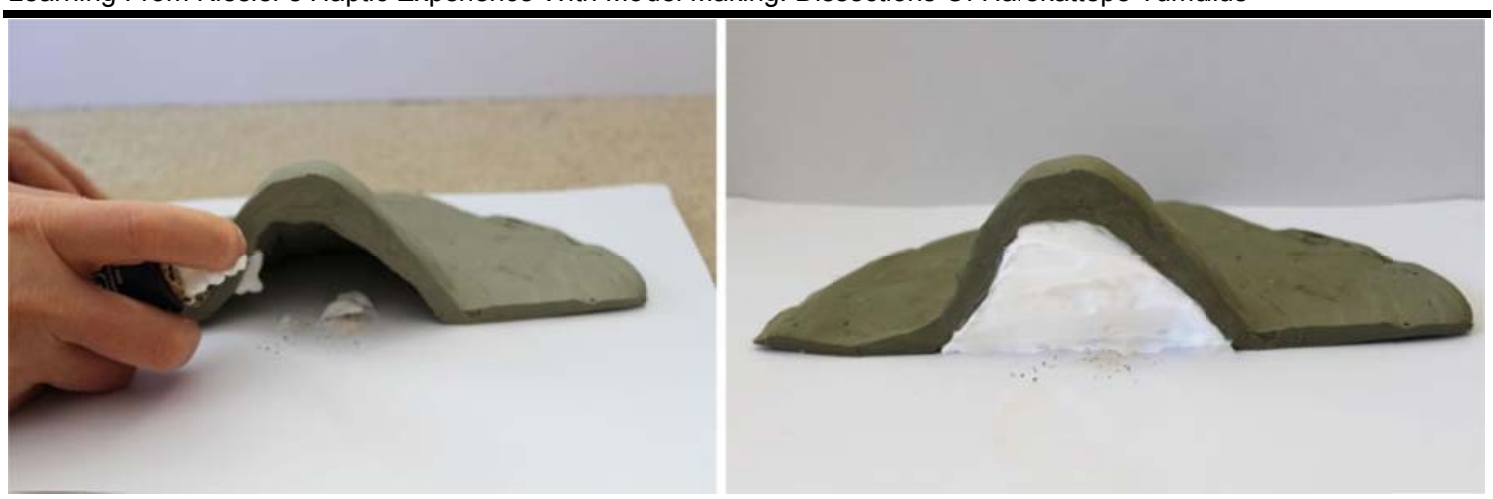

Fig. 9: Intervention to the model. Photo by the author, 2016.

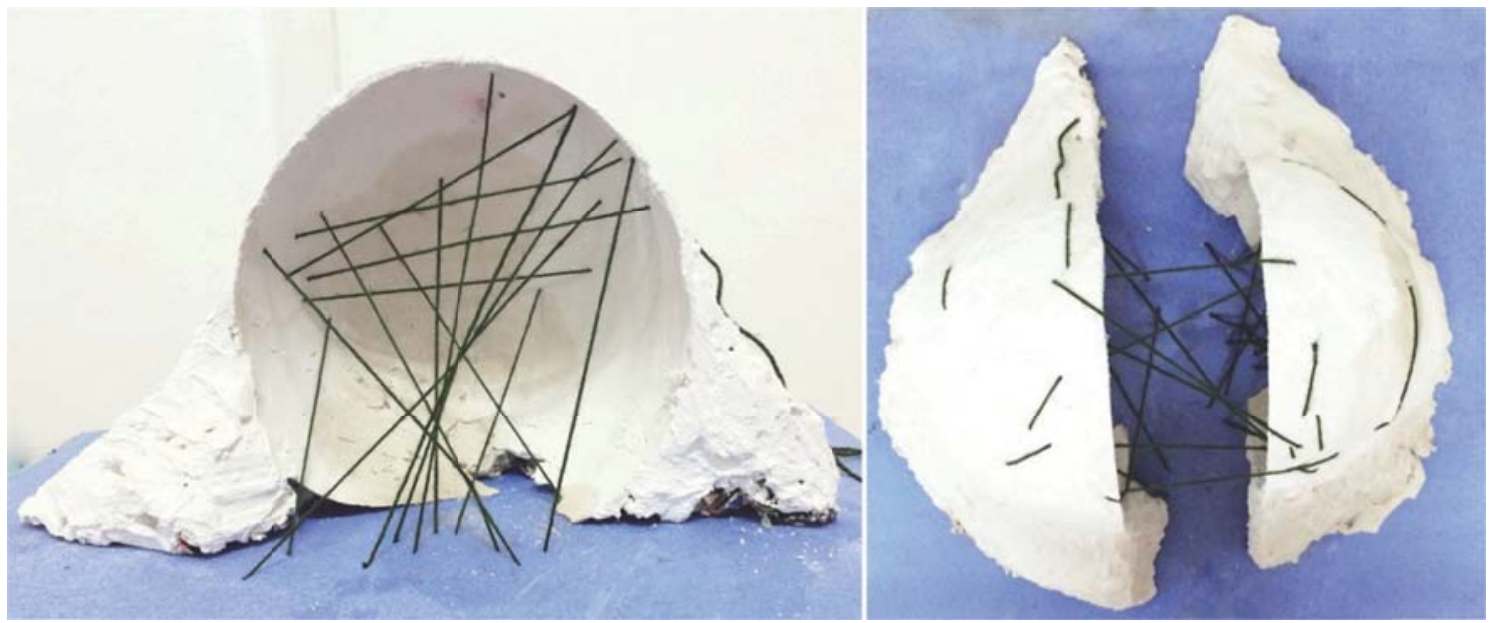

Fig. 10: Intervention to the model. Photo by the author, 2016.
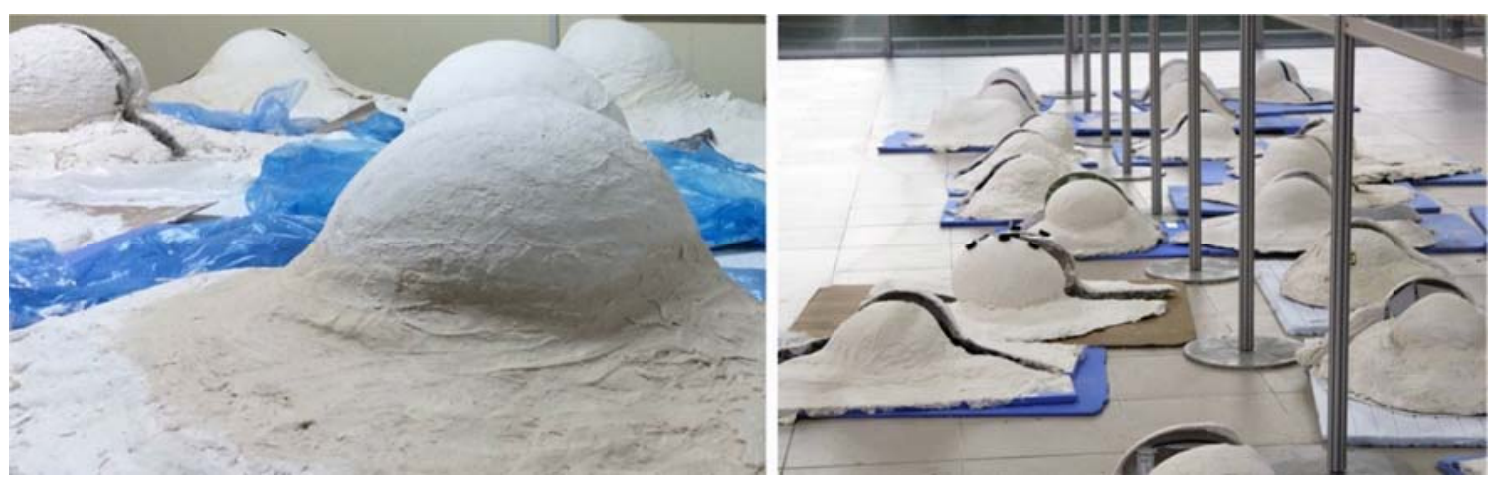

Fig. 11: Plaster and gauze band, model of tumulus by the students. Photo by the author, 2016. 


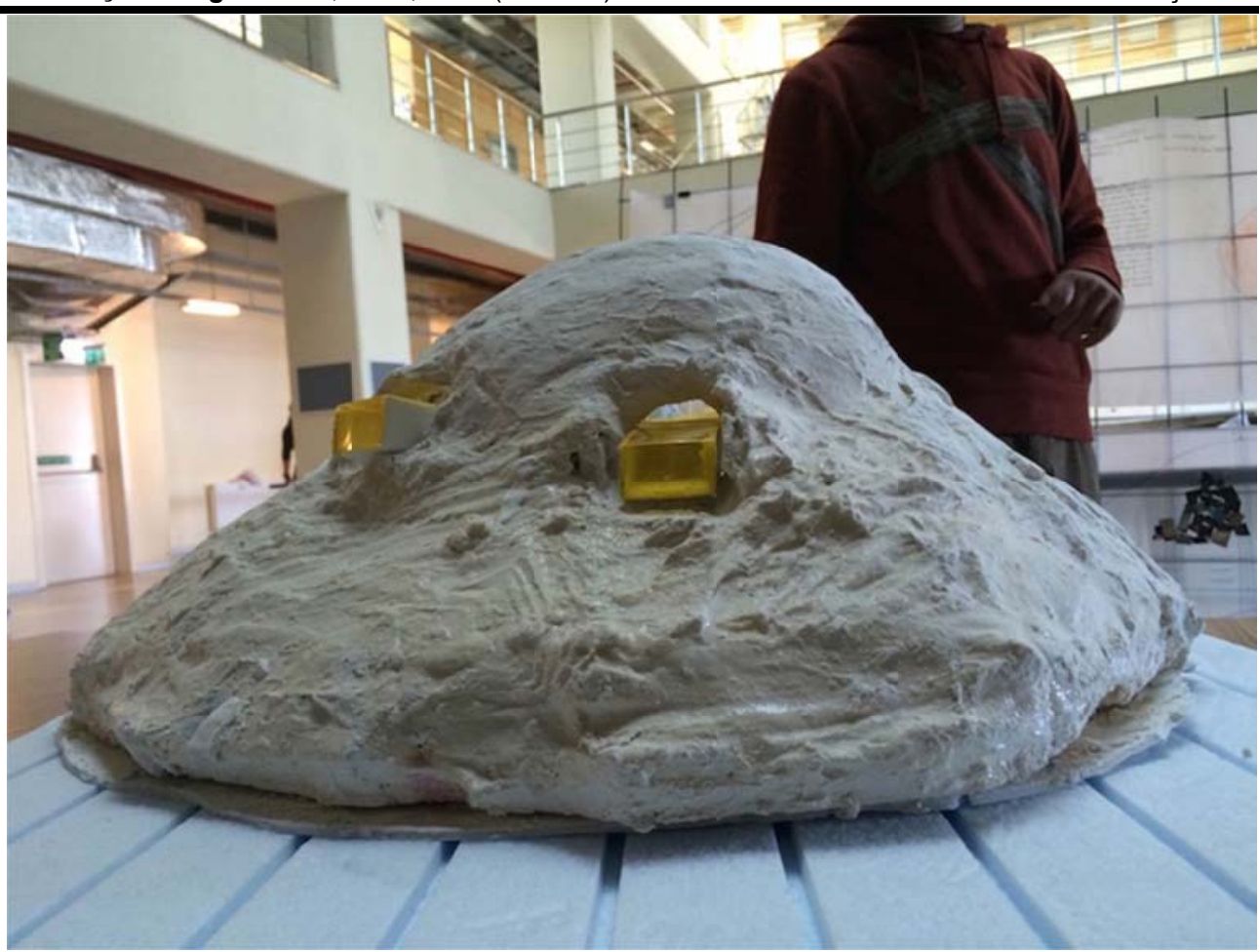

Fig. 12: A dwelling that pops-up from the tumulus by Ömer Faruk Çiftçi, first year student. Photo by the author, 2016.

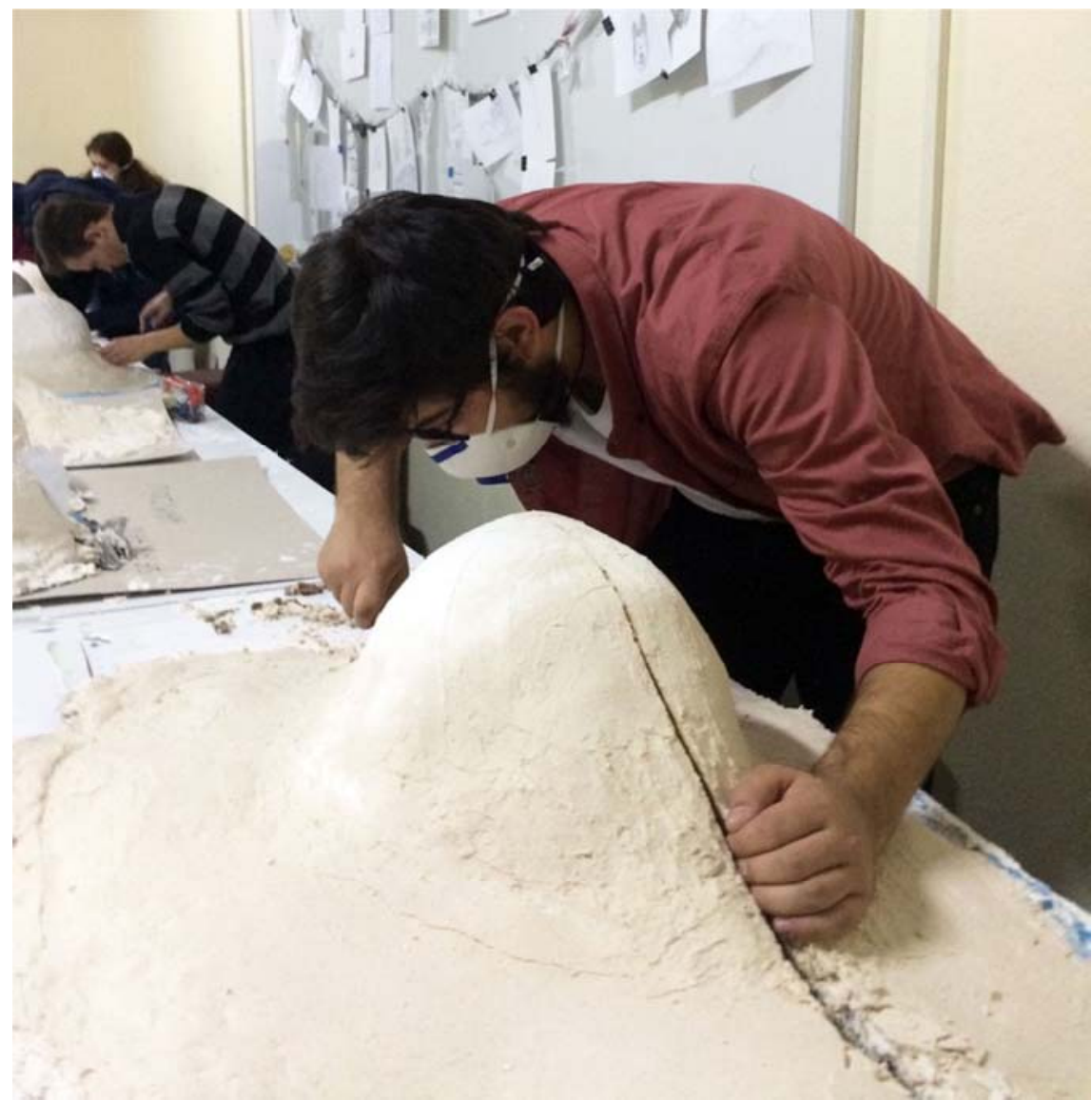

Fig. 13: Dissection of the tumulus, 1/100 scale. Photo by the author, 2016. 
Kiesler'in Model Yapımındaki Haptik Deneyiminden Öğrenme: Harekattepe Tümülüsü'nün Diseksilyonları Learning From Kiesler's Haptic Experience With Model Making: Dissections Of Harekattepe Tumulus

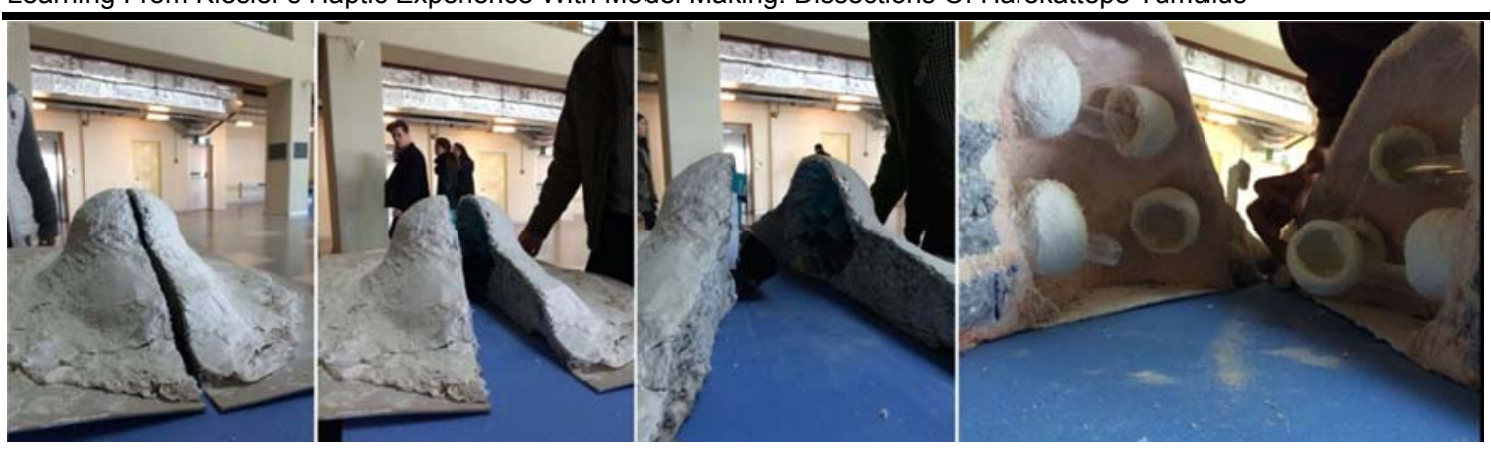

Fig. 14: A dwelling space by Rahmi Ayaz, first year student. Photo by the author, 2016.

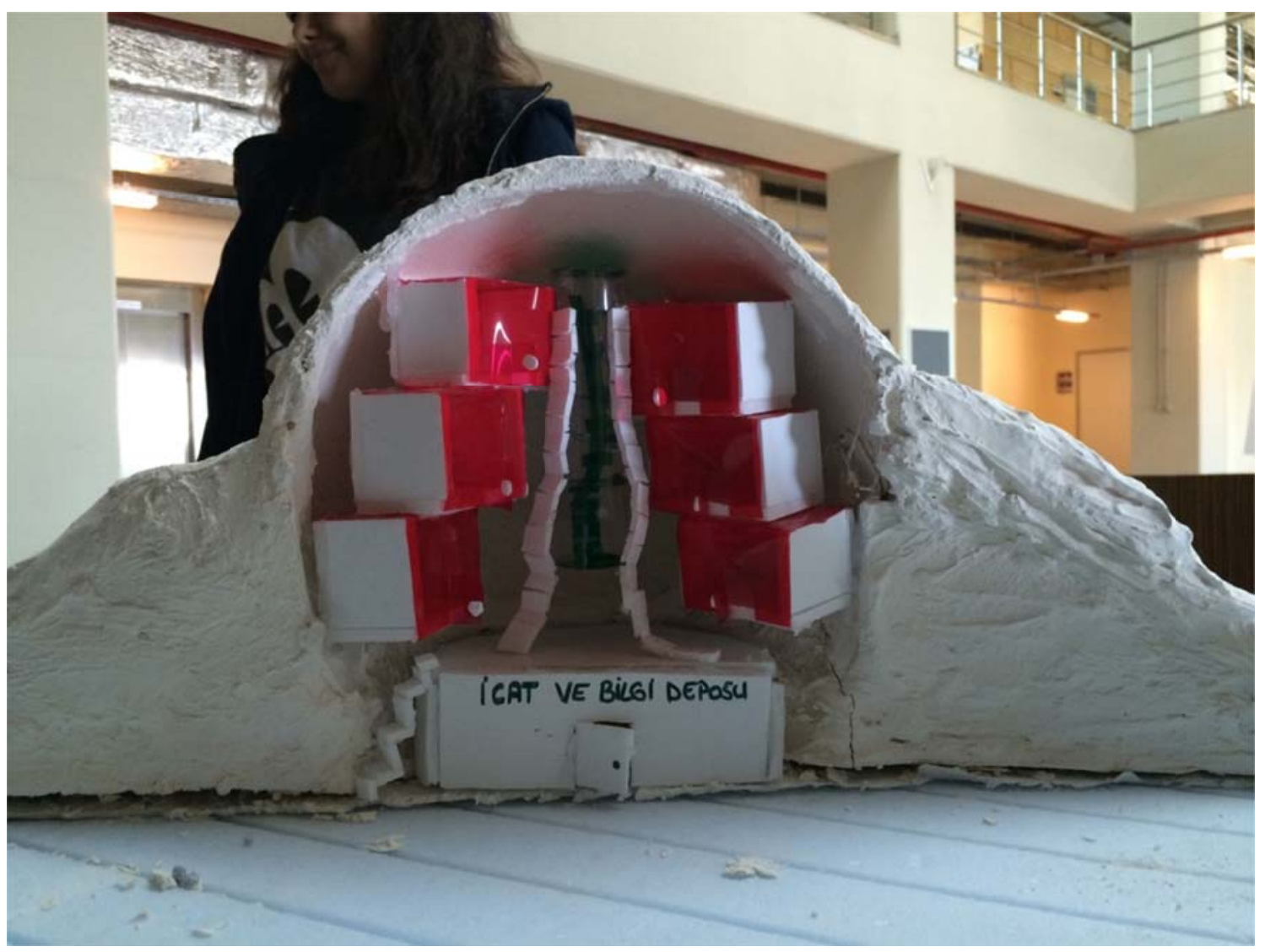

Fig. 15: A discovery centre by Şevval Çapkın, first year student. Photo by the author, 2016. 


\section{GERI DÖNÜŞÜM FABRIKKASI}

Harekattepe

Tümülüsüne yaptı̆̆ııı arazi

gezisi sonrasında başladı̆̆ımız bu

projede

tümülüslerimizin

içinde bir mekan

yaratmaya

calş̧ıtı.Tumulüslerin yapısı beni

birbiriyle bağlantisı olan, tümülüsün için

dolduran, o doluluklarla boş luklar

- içinde 01uşturduğum

yарт

yaratarak ikinci bir mekan olusturmay,

hem kendisiyle hem de dişıyla ikinci

bir mekanı hatta tümüusiesle birlikie

uçuncu bir mekanı yaratt.

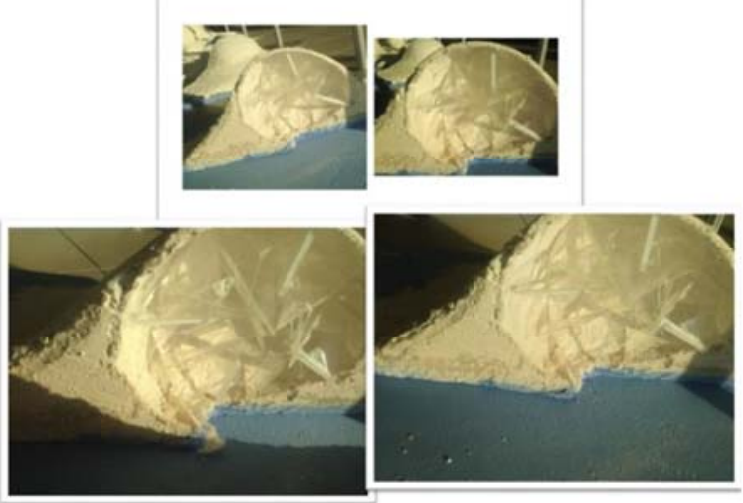

Fig. 16: A recycle factory by Begüm Tüz, first year student. 2016.
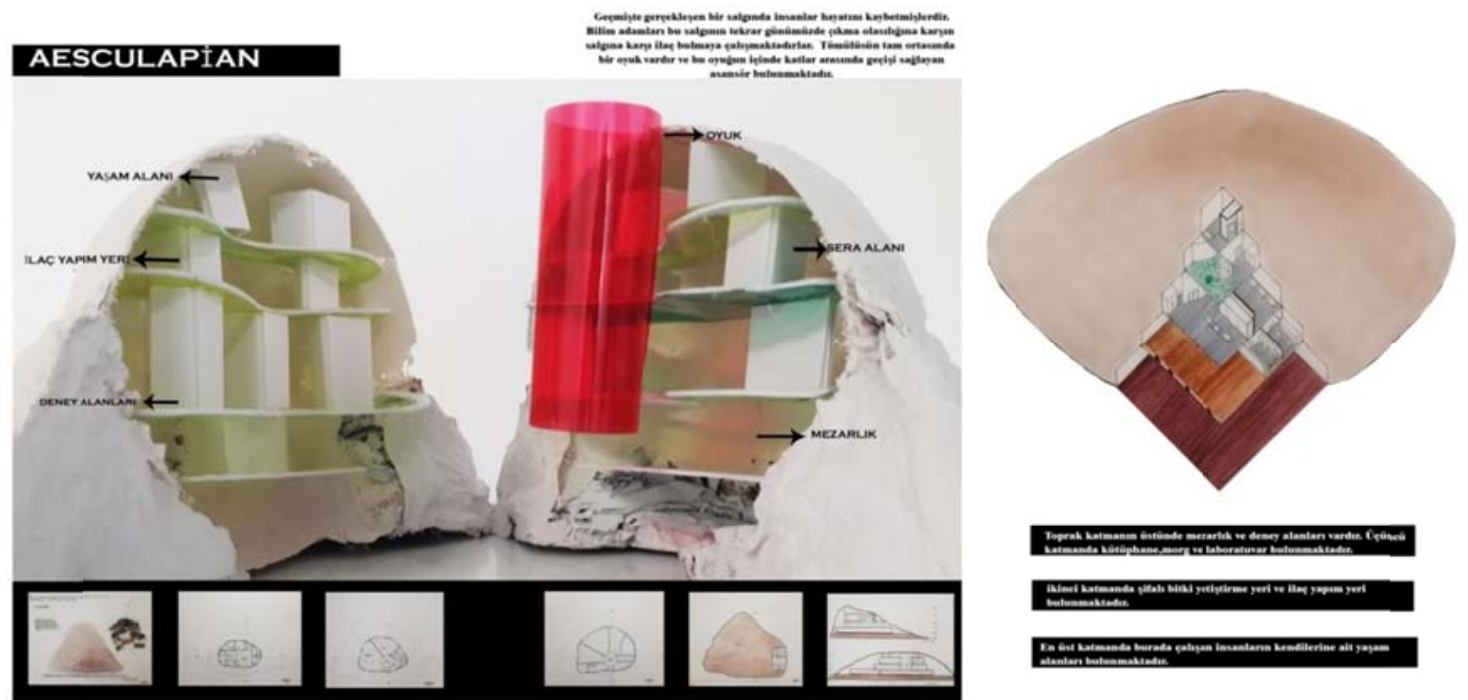

Fig. 17: A medicine and research centre by Aybüke Biçer, second year student, 2016.
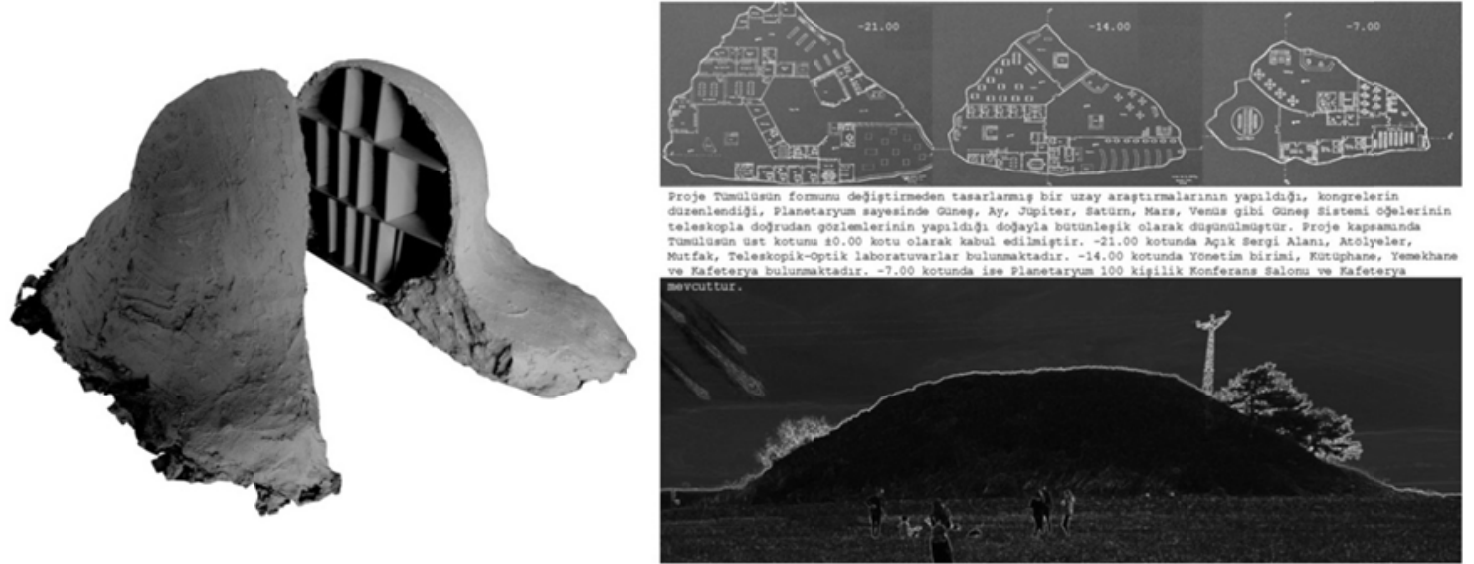

Fig. 18: A space research centre by Abdulkadir Demirel, second year student, 2016. 
Kiesler'in Model Yapımındaki Haptik Deneyiminden Öğrenme: Harekattepe Tümülüsü’nün Diseksiyonları Learning From Kiesler's Haptic Experience With Model Making: Dissections Of Harekattepe Tumulus

Kinaesthetic and haptic perceptions are two linked forms of perception that are defined as a type of intelligence and creativity. Dancers, puppet players and architects have this type of intelligence. In Frames of Mind: The Theory of Multiple Intelligences, Howard Gardner defines bodily-kinaesthetic intelligence in terms of "body movement control, manual dexterity, physical agility and balance, as well as eye and body coordination." His preferred learning style clues are physical experience and movement, touch and feel. He mentions dancers, demonstrators, actors, athletes, etc in this category, but places architects in the spatial-visual intelligence category, which is the "interpretation and creation of visual images; pictorial imagination and expression; understands relationship between images and meanings, and between space and effect" (Anon, 2017).

Kinaesthetic spatial perception is closely linked with spatial-visual perception. "Kinein" means to move and "aesthesis" means the sensory experience gained by this experience. According to Sklar, kinaesthesia is "a sense mediated by the end organs, located in muscles, tendons, and joints and stimulated by bodily movement and tensions," and relatedly, the "sensory experience derived from this sense." "As part of the haptic system, Gibson (1968:111ff) writes of kinesthesia as the perception of the body's movement not as a distinct, individuated sense, but as cutting across several perceptual systems, a sense that utilizes a range of nerve information, including that of muscular tension and balance from the vestibular system, collectively returning sensations of movement" (Paterson, 2012:482).

Not only does kinaesthetic design demolish the boundaries between the subject and object, it also bridges the gap between hapticity and our ocular culture. A growing number of contemporary architectural practices seem to underline kinaesthetic and haptic sensation regarding architects such as Pallasmaa. Some of the examples we confront today exist in biomimetic design or the metaphorical, post-organic context or hyperarchitecture. These approaches recall a distinction between body and spatiality, which has been the main focus of corporeal architecture and which emphasize hapticity. Haptic engagement of the subject and the object becomes essential in these approaches.

Kinaesthetic perception is directly linked to visual and corporeal relations, since a phenomenon is perceived through physical sensors in the muscles. Kinaesthetic perception brings together the human body and sensation. The design process helps students experience bodily-kinaesthetic and spatial perception. The transformation of the experienced environment is used for increasing environmental context awareness. Experiments of kinaesthetic perception transform our perception into a space of perceptions that is at the threshold of subject and object. The threshold is a fusion of senses of form, tactile and sound, into a perceptual habitation space. The role of increasing kinaesthetic awareness in the perception of space may help in demolishing the borders between the subject and object.

Furthermore, kinaesthetic perception through handmade designs enables students to gain sensorial experiences. Touch and vision, as Kiesler mentioned in his designs, became essential to key issues in perceiving the environment. It was observed that most of the students were better at making models in plaster than building their ideas. 
Student designs were then evaluated in terms of their interrelationship between form, program, materiality, tectonics and hapticity. Some of the students found it hard to engage in all these parameters in one single design and thus, designed out of the tumulus's original context, which ended as orthogonal and Cartesian approaches. Others gave more importance to the story behind their designs than the narrative of their design, both through physicality and conceptuality. From all of the designs, it was observed that there was not a difference in approaches between first and second year students, except for the program and scale of their space.

Nearly in all of the designs, form and materiality were evaluated by the students as two distinct matters of design. However, in the Endless House, the use of natural rubber as elastic material enabled the program of the space. Even the rubber became imageless in Kiesler's hands. In the student's works, they were free to develop their own materials or design with the materials they chose. They were previously informed with ambiguous materials, such as bioplastic formation by starch, and were also presented with previous years haptic experiments with soap, plaster and flour based materials that could be handcrafted. The haptic touch of the new materials or materials that established such an interaction could help in developing a new approach to the program of their designs.

In the designs, the gap between design thinking and model making remained two controversial issues. It was also observed that students needed more exercises parallel to this work, such as working with void at different scales throughout different programs or disciplines. The intervention to the tumulus demonstrated that in order to increase the awareness of the students, they needed to engage tectonics within their narratives in a stronger way. An alternative for increasing this awareness may be by getting more intensely focused on dance or corporeal workshops. In turn, these can then be carried out simultaneously with the architectural course, where the students can then experiment on shaping the void through and with their own bodies. Most of these students were confronted with this type of exercise in another design course, the basic design course. Depending on the outcome of this previous workshop a year before, it became necessary to focus more on the mappings of corporeal relations within the space.

As Hill mentions, "The richness of the user's experience of any building depends on an awareness of all the senses, but immaterial architecture may trigger a sense more often associated with the immaterial, such as smell, and question one more often associated with the material, such as touch" (Hill, 2005: 19). In the students' design, the flesh and the body of the tumulus and the narrative of their physical construction were equally important. Tectonics, in this case, was evaluated as an awareness of the space of construction. Many of the student designs were related to tectonics by means of their narratives and the concepts behind their designs, but which could not properly be reflected to the physicality of the designs. For all the designs, topography was evaluated as something triggering a sense of touch, as the oblique idea triggered our bodily movement. Active forms of haptic touch creates context-awareness. 
Kiesler'in Model Yapımındaki Haptik Deneyiminden Öğrenme: Harekattepe Tümülüsü’nün Diseksiyonları Learning From Kiesler's Haptic Experience With Model Making: Dissections Of Harekattepe Tumulus

Paterson defines touch as 'a sense of communication. It is receptive, expressive, and can communicate empathy. It can also bring distant objects and people into proximity' (Paterson, 2007:1). Kinaesthetic sense is triggered by touching and doing together. Why is it important for a student to gain kinaesthetic perception, if he/she won't be a dancer or a corporeal related discipline? As a joined sensation, this perception fuses all other senses through the process of the hand-making model, which increased the student's perception. It may as well develop design for all or universal design related issues.

\section{CONCLUSION}

Dissecting of the tumulus was evaluated as a scientific act for understanding the unconstructed narrative of the tumulus. Design thinking was evaluated in terms of Kiesler's approaches in the Endless House. The aim of intervening the tumulus was to learn design by making within a hands-on studio environment. It was estimated that through this practice, students would be able to observe and design three-dimensional tectonic spaces, in which construction, materials and relations within the outer shell became a super imposing structure. The act of taking sections from the tumulus became more than a physical act and enabled students to perform mental and in-situ physical constructions. Through this playful practice, form was experimented on through learning by doing this approach.

Moreover, students developed their perceptual-motor skills, which involves spatial awareness.

\section{ACKNOWLEDGEMENT}

I would like to thank to my first and second year students and especially to Rahmi Ayaz, Şevval Çapkın, Ömer Faruk Çitfçi, Ömer Aydın, Begüm Tüz, Aybüke Biçer and Abdülkadir Demirel, who contributed their work to this article.

\section{REFERENCES}

Anon, 2017. Retrieved from https://www.businessballs.com/self-awareness/howardgardners-multiple-intelligences-7/.

Costello, C. (2015). Visceral Space: Dissection and Michelangelo's Architecture. Architecture Undergraduate Honors Theses. Paper 12.

Hill, J. (2005). Building the Drawing. Special Issue: Design through Making

July/August, 13-21. Retrieved from http://onlinelibrary.wiley.com/doi/10.1002/ad.v75:4/issuetoc.

Kiesler, F. (2003), Friedrich Kiesler : Endless House, Friedrich Kiesler-Zentrum Wien, Ostfildern-Ruit, Deutschland, Hatje Cantz.

Kiesler, F. (1966), Inside the Endless House: Art People and Architecture: A Journal, Simon and Schuster, New York: 299. 
Krissel, M. (2003). Frederick Kiesler, Inside the Endless House. Retrieved from https://issuu.com/ozgehazer/docs/kiesler (Originally from: www.krisselstudio.com/000docs/2-research/Kiesler.pdf.

Maulden, R. (1986). Tectonics in Architecture: From the Physical to the Meta-Physical. Master of Architecture Thesis, MIT.

Medicus, F. (2010). "Endless House" - a proposed structure. In, From Chicken Wire to Wire Frame, Kiesler's Endless House, Austrian Frederick and Lillian Kiesler Private Foundation. Retrieved from http://www.kiesler.org/cms/media/pdf/From_Chicken_Wire_to_Wire_Frame.pdf (Date of access: 03.05.2017).

Mertins, D. (2007). Where Architecture Meets Biology: An Interview with Detlef Mertins, University of Pennsylvania (Originally published in Interact or Die! edited by Joke Brouwer and Arjen Mulder, pp. 110-131). Retrieved from http://repository.upenn.edu/cgi/viewcontent.cgi?article=1006\&context=arch_papers.

McGuire, L. (2015). Energy, Correalism, and the Endless House. In K. Bollinger and F. Medicus (Eds.), Endless Kiesler (pp. 60-88). Basel: Birkhäuser/Edition Angewandte.

$\begin{array}{llll}\text { Moma } & \text { (a). (2015). } & \text { Retrieved }\end{array}$ https://www.moma.org/explore/inside_out/2015/07/16/the-animation-of-frederickkieslers-endless-house/.

Moma (b). (2017). Retrieved from https://www.moma.org/artists/3091?locale=en (originally from Frederick Kiesler, "Pseudo-Functionalism in Modern Architecture," Partisan Review 16 (July 1949), 738).

Paterson, M. (2007). The Senses of Touch: Haptics, Affects and Technologies. Berg: Oxford and New York.

Paterson, M. (2012). Movement for Movement's Sake? On the Relationship Between Kinaesthesia and Aesthetics, Essays in Philosophy: vol. 13: Iss. 2, Article 7. http://dx.doi.org/10.7710/1526-0569.1433.

Phillips, S. (2017). Elastic Architecture: Frederick Kiesler and Design Research in the First Age of Robotic Culture. MIT Press.

Phillips, S. (2005). Introjection and Projection: Frederick Kiesler and His Dream Machine. In, T. Mical (Ed.) Surrealism and Architecture (pp. 140-155).

Stiles, K. (2012). Theories and Documents of Contemporary Art: A Sourcebook of Artists' Writings, University of California Press, Originally from Kiesler, 'Second Manifesto of Correalism', Art International 9, no. 2 (March 1965), pp. 16-19.

Sveiven, M. (2011). Retrieved from http://www.archdaily.com/126651/ad-classicsendless-house-friedrick-kiesler.

Wilde, S., \& Ferber, S. (2012). The History of Medicine in Context: The Body Divided: Human Beings and Human 'Material' in Modern Medical History. Routledge. 
Kiesler'in Model Yapımındaki Haptik Deneyiminden Öğrenme: Harekattepe Tümülüsü'nün Diseksiyonları Learning From Kiesler's Haptic Experience With Model Making: Dissections Of Harekattepe Tumulus

Vyzoviti, S., (2004). Folding Architecture: Spatial, Structural and Organizational Diagrams. Amsterdam: BIS Publishers.

Yıldııı, Ş., (2011). Doğu Trakya'da Mezar Tepelerinin Ortaya Çıkışı ve Gelişimi, Ankara Üniversitesi Sosyal Bilimler Enstitüsü, Ankara.

Zillner, G. (2010). From Chicken Wire to Wire Frame Kiesler's Endless House, Austrian Frederick and Lillian Kiesler Private Foundation. Retrieved from http://www.kiesler.org/cms/media/pdf/From_Chicken_Wire_to_Wire_Frame.pdf. 